\title{
Conquista feudal y transformaciones agrarias: colonización agrícola y ganadería en el prado de Tortosa, siglos XII-XIII
}

\author{
ANTONI VIRGILI
}

PALABRAS CLAVE: colonización, prado, acequias, ganadería.

\section{CÓDIGOS JEL: N53, N93, Q15, Q25.}

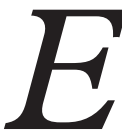

l objetivo del artículo es documentar y describir los primeros procesos de colonización del prado de Tortosa a raíz de la conquista cristiana, en 1148. Se inscribe en una línea historiográfica que pone de relieve el impacto de las conquistas de los reinos cristianos de la península Ibérica sobre al-Ándalus e incide, en especial, en las modificaciones que los conquistadores introdujeron en el paisaje agrario andalusí para adaptarlo a sus necesidades: los intereses señoriales relacionados con la producción y captura de la renta feudal. Para ello, se ha analizado la documentación generada por la conquista, cuya información ha sido contrastada con los resultados de la prospección, el trabajo de campo y el estudio cartográfico. Se han identificado los espacios agrarios y descrito los componentes del paisaje: las redes de acequias, los caminos, un molino harinero, cuevas, mansos y extensas áreas de prado jalonadas por charcas y lagunas. Los conquistadores ampliaron la red de desagüe y construyeron parcelarios territorialmente homogéneos, aunque discontinuos, de viñedos, huertos y tierra campa para sembrar. Sin embargo, amplias zonas del prado continuaron siendo tierra de pastos para la ganadería. 


\title{
Feudal conquest and agrarian transformations: agricultural colonization and livestock on the Tortosa plain in the twelfth and thirteenth centuries
}

\author{
KEYWORDS: colonisation, meadow, canals, livestock.
}

\author{
JEL CODES: N53, N93, Q15, Q25.
}

his paper examines the earliest colonisation of the Tortosa plain, following the
Christian conquest of 1148 . The research follows a historiographic line that
highlights the impact of the conquest of al-Andalus by Christian kingdoms from the north of the Iberian Peninsula. It focuses especially on the modifications that the conquerors made to the Andalusian agrarian landscape, aimed chiefly at increasing production and feudal rents. The research methodology involved examining the documentation generated by the conquest, then comparing and contrasting it to archaeological survey work, field work and study of available maps. Agrarian spaces are identified and landscape features described, including networks of drainage canals, roads, a flour mill, caves, estates (mansi) and large meadows dotted with ponds and lagoons. The conquerors expanded the drainage infrastructure and divided the land into homogenous, but not necessarily contiguous, field systems with vineyards, green gardens, and plots for dryland agriculture. However, large areas remained uncultivated for grazing..

Recepción: 2019-04-03 - Revisión: 2019-11-02 - Aceptación: 2019-11-05

Antoni Virgili [orcid.org/0000-0001-5952-9791] es profesor agregado de Historia Medieval en la Universitat Autònoma de Barcelona. Dirección para correspondencia: Departament de Ciències de l'Antiguitat i l'Edat Mitjana, Facultat de Lletres, Edifici B, 08183, Cerdanyola del Vallès (España). C. e.: antoni.virgili@uab.cat 


\section{INTRODUCCIÓN}

El presente trabajo se inscribe en una línea de investigación que tiene por objetivo primordial calibrar el impacto y las consecuencias de las conquistas cristianas sobre los espacios agrarios construidos, explotados y gestionados por las sociedades vencidas y objeto de estas conquistas. Las modificaciones que introdujeron los conquistadores respondían, evidentemente, a las necesidades de una población nueva que había sustituido totalmente o en parte a la población autóctona a través de flujos migratorios procedentes de las distintas regiones de la cristiandad. El asentamiento de colonos en los territorios conquistados conlleva, como no puede ser de otra manera, la organización de nuevas formas de poblamiento y nuevas formas de gestionar y aprovechar los recursos en función del orden político y social feudal impuesto en el conjunto de las regiones periféricas de la cristiandad europea (Bartlett, 2003). La imposición de las nuevas pautas agrarias introdujo cambios ecológicos y medioambientales de relieve en los paisajes urbanos y rurales (Pluskowsky, Boas \& Gerrard, 2011; Torró, 2019).

Uno de los escenarios de la expansión de la cristiandad fue al-Ándalus. Desde hace un par de décadas se ha avanzado muy significativamente en el conocimiento de las transformaciones del espacio rural andalusí a raíz de las conquistas protagonizadas por las sociedades feudales del norte peninsular, en buena medida a partir de las propuestas de Thomas F. Glick (2007). Los procesos de colonización introdujeron una profunda ruptura con relación a la sociedad y los paisajes anteriores a la conquista: el desplazamiento y el asentamiento de colonos cristianos, y la apropiación del territorio mediante los repartimientos los modificaron profundamente. Se dejaron de cultivar campos mientras se roturaban otros o se ampliaban los sistemas hidráulicos, siempre en función de los conocimientos, las soluciones técnicas y las necesidades de los conquistadores, impuestas por la exigencia de renta o los patrones alimentarios, entre otras, orientando la actividad agraria a producciones de carácter extensivo, especulativas y especializadas para atender la demanda de mercados urbanos e interregionales (Malpica, 2015; Torró \& Guinot, 2018).

El alcance de los estudios orientados a estos objetivos se extiende al conjunto de los reinos feudales peninsulares que impulsaron la conquista y a las regiones de al-Ándalus afectadas por esas dinámicas en todo el arco cronológico del proceso (siglos XI-XVI), así como a los medios aplicados por los conquistadores en los distintos paisajes en los que intervinieron. Las investigaciones se han desarrollado mediante el análisis combinado de las fuentes y procedimientos derivados de la documentación escrita, la arqueología, la cartografía y el estudio de los parcelarios (Ballesteros et al., 2010). 
Para el siglo XII, contamos con investigaciones relativas al impacto de las conquistas cristianas sobre la población y los espacios rurales andalusíes en los asentamientos y espacios de cultivo en el valle del Ebro en Aragón que contrastan la agricultura de los vencidos y la de los vencedores (Ortega, 2010), así como la construcción de redes de acequias, como en Teruel (Laliena \& Ortega, 2012). Por su parte, G. García-Contreras $(2018,2019)$ ha estudiado la introducción de las nuevas pautas agrarias feudales en el sector oriental de la extremadura castellana (Guadalajara), entre los siglos XI-XIII, donde se realizaron obras de drenaje para acondicionar la tierra para poder cultivar cereales y viña, sin dejar de practicar la silvicultura y potenciar la actividad ganadera, facilitada por la explotación salinera de la zona. La conquista catalana del valle del Segre y del Bajo Ebro cuenta también con distintos estudios, como los de M. Monjo (2012) sobre la baronía de Aitona, al sur de Lérida, y las investigaciones en torno a la ciudad de Tortosa (Virgili, 2010a; Puy et al., 2014; Kirchner \& Virgili, 2018), en las que se pone de relieve el acondicionamiento de amplias superficies de humedal para ampliar el área de cultivo de cereales y viña.

A raíz de las grandes conquistas del siglo XIII, los reinos cristianos peninsulares duplicaron el territorio bajo su dominio. A pesar de las diferencias de escala en los procesos de colonización de las distintas regiones conquistadas, según la capacidad de canalizar flujos migratorios, y de la diversidad de paisajes sobre los que se intervino, se observan pautas comunes. Helena Kirchner (1995, 2003, 2012) y Josep Torró (1995, 1999, 2003) han puesto énfasis en los cambios que la gestión colonial feudal provocó en los asentamientos y los paisajes rurales andalusíes en los reinos de Mallorca y Valencia, y la necesidad de la práctica arqueológica en el estudio de los núcleos residenciales, los campos de cultivo y las modificaciones en los sistemas hidráulicos por parte de los conquistadores. La colonización feudal amplió los espacios de cultivo mediante el avenamiento de áreas palustres cercanas al litoral con la finalidad de proporcionar tierra a los colonos cristianos (Torró, 2010, 2012; Torró \& Esquilache, 2018). En Ibiza se produjo un proceso semejante (González Villaescusa \& Kirchner, 1997). Por su parte, Enric Guinot ha estudiado las transformaciones llevadas a cabo en la huerta de Valencia, así como en zonas de secano, a partir de las directrices feudales (Guinot, 2003, 2018; Guinot \& Selma, 2012).

Julián Clemente (2018) ha puesto de relieve la importancia de los espacios incultos, la práctica ganadera y la ampliación de los cultivos de cereal y viña en Extremadura. Por su parte, Emilio Martín $(2016,2018)$ ha estudiado el aprovechamiento de los humedales, la complementariedad de las actividades agrícola y ganadera, y las transformaciones a raíz de la conquista en la región de Cádiz. Mientras, Carmen Trillo (2012) y María Antonia Carmona (2018) han trabajado los cambios en Granada y el valle del Guadalquivir a partir de la colonización feudal. Asimismo, han sido objeto de atención las diferencias entre la agricultura de los mudéjares (luego moriscos) y la de los cristianos en 
asentamientos duales, como en Aitona (Lérida) (Monjo, 2012), o Igualeja (Málaga) (Díaz Sierra, López García \& Retamero, 2018).

\section{EL PRADO DE TORTOSA}

El estudio del prado de Tortosa forma parte de un proyecto de más alcance sobre la organización del espacio agrario en época andalusí y el más inmediato a raíz de la conquista cristiana de Madînat Țurțûsa. La ciudad andalusí capituló ante el conde de Barcelona, Ramon Berenguer IV, el Común de Génova y otros aliados el 31 de diciembre de 1148, tras seis meses de asedio (Virgili, 2001b). La campaña formaba parte de un mismo proyecto de conquista que incluía la toma de Lérida (octubre de 1149), y se sitúa en el contexto de la Segunda Cruzada decretada en 1145 por el papa Eugenio III mediante la bula Quantum Praedecessores (Phillips, 2007), expresión del fenómeno cruzado de expansión de la cristiandad latina (Bartlett, 2003). En 1149, el conde de Barcelona otorgó una carta de población en la que delimitaba el territorio de la ciudad (Font Rius, 1969: doc. 15). El inmediato proceso de repartimiento dio lugar a la constitución de los señoríos feudales y puso las bases de la colonización cristiana protagonizada por centenares de familias de diversa procedencia (catalanes, occitanos, genoveses, aragoneses y anglonormandos) que se asentaron en el territorio de Tortosa a través de flujos migratorios constantes para sustituir a la población autóctona, muy reducida de efectivos tras la conquista (Virgili, 2001c, 2007, 2009, 2010b, 2019).

La documentación conservada es rica en información sobre el espacio agrario que encontraron los conquistadores y el desarrollo de las transformaciones de que fue objeto a lo largo de los siglos XII-XIV. La información textual, contrastada con la obtenida de la prospección y el trabajo de campo, permite interpretar los perfiles de este paisaje antes de los cambios experimentados en el cauce del Ebro a raíz de la construcción de los canales, los pantanos y el cultivo de grandes extensiones de arrozal.

Una de las novedades se centró en la roturación de espacios incultos, hasta entonces destinados a otros usos. La ampliación de los espacios de cultivo se produjo, en un principio, en terrenos adyacentes a las orillas fluviales, pero sobre todo en las zonas de prado, al sur de Tortosa, en los tramos más cercanos a la desembocadura del Ebro. Los colonizadores tenían ante sí grandes extensiones de terreno que podían convertir en tierra de labor previo acondicionamiento de marjales e ínsulas fluviales (algeziras) ${ }^{1}$. El proceso

1. Con el término algezira(s), del árabe al-jazira (isla), en los documentos se designa a unos espacios adyacentes al curso fluvial con el agua rodeando alguno o varios de sus límites. Las algeziras fi- 
afectó poderosamente al medio y supuso la sustitución parcial de unos aprovechamientos ancestrales de caza, recolección y pastos para la ganadería, por cultivos especulativos de viña, cereal y frutales, según los intereses de la oligarquía dirigente.

En este trabajo se aborda el estudio de los programas iniciales de colonización del prado de Tortosa desarrollados por los conquistadores en los sectores de Aguilen (Algilen, Aquilen, Aquileyn, Aquileny) y Quint, o Quinto (hoy Campredó, municipio de Tortosa), y Burjassénia (término de L'Aldea), donde la catedral de Tortosa y, sobre todo, la encomienda del Temple acumularon un importante patrimonio.

La particularidad de los paisajes objeto de nuestro estudio es que están situados en una zona muy cercana a la desembocadura del Ebro. En conjunto, se trata de un espacio de gran superficie, de unos cincuenta kilómetros cuadrados, aproximadamente. Sin embargo, la documentación conservada permite realizar un estudio detallado de los procesos iniciales de roturación. El área de Aguilen y Quint constituye una estrecha franja encajonada entre el río y un acantilado de pronunciada pendiente cuyo terreno está sujeto a acumulaciones del agua que aportan los barrancos, el propio río y los numerosos manantiales que afloran en la superficie (ullals). La inestabilidad de la orilla fluvial, jalonada de brazos de río y acumulaciones periódicas de agua, explica las dificultades para poner la tierra en cultivo.

Burjassénia, un poco más al sur, ya en plena llanura deltaica, se caracterizaba por ser un espacio de gran superficie punteado de lagunas y charcas. Se trataba de un sector todavía más dinámico por la incidencia directa del Ebro. La existencia de una torre y una noria facilita una asociación con el topónimo árabe burj as-saniya, o torre de la noria, a partir del cual se ha fundamentado su origen andalusí (Martí \& Negre, 2014, 2016). Sin embargo, el estudio arquitectónico, la misma voz burj, que significa también casa de campo (Kirchner et al., 2016), y las primeras menciones de la torre en la documentación latina, ya tardías, a partir de 1197 (Virgili, 2001a: doc. 553), parecen indicar que nos hallamos ante un topónimo de indudable origen árabe, pero de un nuevo asentamiento, con una torre, constituido a partir de la conquista cristiana (Mateu, 2016). Sendos documentos mencionan uno o varios rahales, sin duda los emplazamientos andalusíes primigenios de este sector, pero que no parecen haber tenido continuidad en el nuevo asentamiento, origen del actual. Un documento de 1167 menciona un arrahal antiquo a levante de una tierra con huerto, pozo y una viña, mientras que el de 1197 hace referencia a totum man-

guran casi siempre en zonas cerradas por pronunciados meandros, a lo largo del curso bajo del Ebro. A raíz del dominio cristiano los nuevos señores pusieron en marcha estrategias de aprovechamiento y cultivo de estas tierras (KIRCHNER \& VIRGILI, 2018). 
sum de Boriacenia, cum omnibus domibus et turre, et cum omni honore heremo et laborato et cum arrafals $[\ldots]^{2}$.

\section{FIGURA 1}

Principales asentamientos en el curso bajo del Ebro

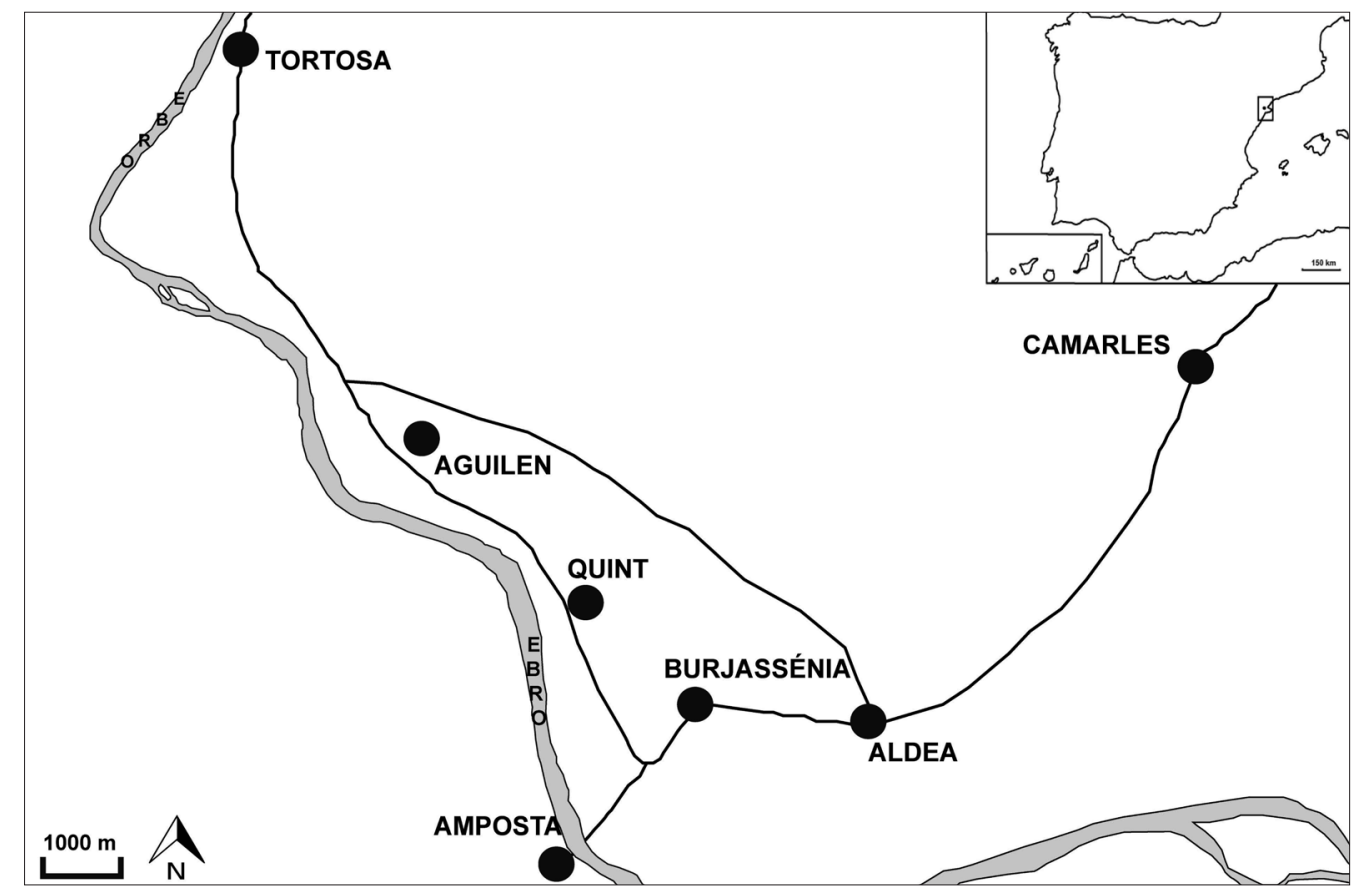

Fuente: A. Virgili.

Los documentos más antiguos se refieren a esos lugares como zonas de prado. Describen un paisaje natural muy poco antropizado y en permanente transformación por los efectos del gran río que encaja con el concepto de riparia, en referencia a la interacción entre la sociedad y un medio físico lacustre del que se obtienen numerosos recursos (pastos, caza, pesca, sal, etc.) y que a menudo requiere una cierta gestión del agua (Hermon, 2014). El aprovechamiento de los espacios incultos, entre los que figuran los humedales como los que se han descrito, cuestiona la visión negativa de unos ecosistemas hostiles desde una óptica urbana. Justo lo contrario, veremos cómo la ciudad de Tortosa luchó de forma insistente para acceder a los pastos de la zona. A raíz de la conquista, la población andalusí fue desalojada de allí. Desconocemos los procedimientos utilizados (deporta-

2. Archivo de la Corona de Aragón (ACA), OO. MM., Gran Priorat, Tortosa, códice 115, d. 44, f. 14; VIRGILI (2001a: doc. 553). 
ciones, expulsiones, traslados y desplazamientos forzosos o fugas masivas), pero lo cierto es que los textos no muestran ni un solo indicio de permanencia. Así, los colonos cristianos fueron los únicos que protagonizaron la ocupación y la explotación de estas tierras ${ }^{3}$.

El espacio, en su conjunto, ha sido profundamente modificado a lo largo del último siglo. Entre las obras más significativas destacan la construcción del canal de l'Esquerra de l'Ebre, inaugurado en 1912, la construcción de la vía férrea entre L'Aldea y Tortosa y el actual trazado de la carretera C-42 (Eix de l'Ebre: Tortosa-Lleida), que ha sustituido la antigua vía. La actuación más agresiva se debe a la construcción del polígono industrial Baix Ebre, iniciado en 1976, que ocupa la mayor parte del sector septentrional de Campredó, entre la carretera y el canal. En 1989 se construyó la estación de bombeo del minitrasvase del Ebro con el objeto de abastecer de agua el área metropolitana de Tarragona. En otro sentido, la moderna colonización agraria también ha modificado el paisaje al ganar espacios de cultivo hasta el lecho fluvial, actualmente encauzado, en áreas que los testimonios orales recuerdan como incultas y acumulaciones de limos. Así, se ha construido un nuevo parcelario de huerta y, a medida que se avanza hacia el sur, de arrozales.

A pesar de todo, quedan algunas zonas de marjal con la vegetación asociada (juncos, cañaverales, chopos y otras especies de ribera). La más extensa cubre todavía una considerable franja entre una calle del polígono y el roquedal, bajo protección en la actualidad: el marjal de Campredó; hay otras áreas de estas características un poco más al norte, entre la vía férrea y el canal. A pesar de la espesura de la vegetación es todavía perceptible el trazado de una de las acequias de desagüe, dispuesta de norte a sur. En el acantilado se abren un buen número de cuevas de dimensiones variadas, utilizadas tradicionalmente para cobijar ganado e, incluso, como viviendas.

\section{EL DOMINIO TEMPLARIO DEL PRADO DE QUINT Y BURJASSÉNIA}

La encomienda del Temple de Tortosa logró acumular un importante patrimonio en el prado de Quint y Burjassénia. En 1157 obtuvo, mediante permuta, dos piezas de tierra situadas en Quint (Pagarolas, 1984: doc. 9). La consolidación del dominio territorial, no obstante, se produjo a raíz de la donación del prado realizada por Alfonso el Casto en marzo de 1176, con los estaños, situado desde la Pedrera (cantera) de Amposta hasta el manso de Guillem de Sant Cugat, y entre el Ebro y las garrigas ${ }^{4}$. El 9 de junio del mismo

3. A mediados del siglo XIII, la orden del Hospital estableció una comunidad islàmica procedente de Silla (Valencia) en el núcleo adyacente de L'Aldea (VIRGILI, 2019: 58-61).

4. [...] supradictum pratum, cum stagnis [...] et terminatur ab una parte in flumine Yberi et ex aliis tri- 
año Ramon de Montcada confirmaba la donación (Pagarolas, 1984: doc. 63). El documento hace constar que los Montcada tenían el prado por donación real, con un molino, una acequia y unos campos.

A fines de noviembre de 1179, Alegret de Altafulla permutaba con el Temple su honor ${ }^{5}$ del prado a cambio de otros dos campos en el mismo sector (Pagarolas, 1984: doc. 68). En noviembre de 1182, Ramon de Montcada ratificaba la posesión templaria del prado a cambio de mil morabetinos (Pagarolas, 1984: doc. 78). En abril de 1197, Ramon de Montcada confirmó la donación de una viña en este mismo lugar, que su padre ya había donado al Temple de Tortosa. De esta viña, con sus árboles, se dice que estaba cercada ${ }^{6}$.

El dominio templario en este sector siguió ampliándose. Mediante una permuta formalizada en 1185 la encomienda obtuvo otro campo en Quint (Pagarolas, 1984: doc. 89), y en 1201, adquirió un honor que limitaba al sur y al oeste con tierras de la propia orden (Ibíd.: doc. 120). La finalidad de estas operaciones era añadir nuevas piezas al dominio inicial.

Las posesiones templarias del prado de Quint enlazaban con las de Burjassénia. Solo contamos con dos adquisiciones documentadas de los templarios en ese lugar, ya tardías: la compra de un honor, en 1210, y la recepción de un campo por donación de Joan de Puig, en 1219 (Pagarolas, 1984: doc. 131; Pagarolas, 1999b: doc. 17). Hay, sin embargo, referencias indirectas al dominio templario en fechas anteriores. A raíz de la concesión de Tortosa a la orden por Alfonso el Casto en 1182, se realizó un inventario de los bienes de la encomienda, entre los que figuraba illam combam quam Raimundus de Montechateno donavit supradicte domui, que comba est in pratum Quinti et Burgaçeniam (Pagarolas, 1999b: doc. 206), y confirmada en otra relación de bienes del año 1184 (Pagarolas, 1984: doc. 81). En otro inventario, de 1210, se hace referencia al mismo inmueble (Ibíd.: doc. 134). La orden debía tener este patrimonio en gran estima, ya que decidió retenerlo cuando en 1294 efectuó una permuta por la que renunció al señorío sobre Tortosa a favor de la monarquía (Pagarolas, 1998). Entre los bienes que decidió conservar figura castrum seu locum vocatum Buriaçenia, et turrim seu domum vocatam lo prat, cum suis honoribus et possessionibus, hereditatibus, oliveriis, pratis, devesiis et aliis suis pertinen-

bus partibus clauditur ab ipsis garricis usque in iamdictum flumen Yberi (PAGAROLAS, 1984: doc. 60).

5. En los textos latinos utilizados, la voz honor tiene diversos significados en función del contexto, pero el denominador común es que siempre se refiere a un patrimonio inmueble o al usufructo vinculado a este patrimonio.

6. [...] vineam [...] sicut est fundatam et hedificatam inter illis parietibus et clausuris [...] cum omnibus arboribus (Pagarolas, 1984: doc. 110). 
ciis universis et plura alia (Pagarolas, 1999b: doc.180; Fuguet, 1998). Burjassénia siempre se asocia al honor del prado, formando una unidad territorial homogénea.

En definitiva, Burjassénia, mencionada por primera vez en $1167^{7}$, se afianza a partir de la década de los ochenta del siglo XII, para consolidarse en la siguiente. El topónimo es calificado en varias ocasiones como término (Pagarolas, 1984: doc. 131; Pagarolas, 1999b: docs. 17, 48, 49, 50, 51, 53, 55, 60), y también como manso, lugar, castrum y to$\mathrm{rre}^{8}$. En fechas tardías, a partir de 1243, se empieza a calificar de villa (Pagarolas, 1999b: doc. 61), coincidiendo con un importante proceso de urbanización por parte del Temple, mediante la concesión de casas y solares, como se verá.

Las dignidades templarias administraron el conjunto patrimonial formado por el prado de Quint y Burjassénia a través del centro conocido como la Casa del Prat (popularmente llamada torre de la Llotja, y también del Caragol). Los restos muestran un edificio de forma cúbica situado en un cerro a cuyos pies se extiende la llanura fluvial de lo que constituía el prado. Está rodeado de una muralla perimetral irregular, colmatada en su mayor parte, que reproduce el contorno del altiplano. La prospección practicada en este entorno dio como resultado el hallazgo de fragmentos de cerámica islámica en superficie, por lo que constituye un yacimiento con un notable potencial arqueológico. Desde fines del siglo XII, el Temple concibió este dominio como una dependencia subordinada a la encomienda de Tortosa, a cuyo cargo situó un subcomendador o camarero (Pagarolas, 1999a: 145-147).

\section{LA COLONIZACIÓN DE AGUILEN Y PRADO DE QUINT}

Los documentos más antiguos corresponden a las concesiones condales del proceso de repartimiento, y distinguen los distintos espacios agrarios del prado. De norte a sur, el primer topónimo corresponde a Aguilen. En 1154, el conde donó a su vasallo y baile condal en Tortosa, Guillem de Copons, tierra para sembrar 25 cuarteras de semilla (alrededor de $62.000 \mathrm{~m}^{2}$ ) en el prato algezire, las cuevas situadas sobre este prato Algiren, así como tierra para sembrar 15 cuarteras (poco menos de $37.000 \mathrm{~m}^{2}$ ) en el lugar llamado Occulis Lupi ${ }^{9}$.

7. ACA, OO. MM., Gran Priorat, Tortosa, códice 115, d. 44, f. 14.

8. ACA, OO. MM., Gran Priorat, Tortosa, códice 115, d. 44, f. 14; PAGArolas (1999b: docs. 52, 56, 80, 180); VIRGILI (2001a: doc. 553). En este último documento se califica de castrum seu locum.

9. Sobre la reducción de las antiguas medidas de superficie al sistema actual, véanse ALSINA, FELIU y MARQUeT (1990: 215-218) y Virgili (2001b: 205-209). No hemos podido identificar ni localizar 
En 1182, Guillem de Sant Cugat compraba a Pere Cavaller los derechos sobre un manso en Aguilen, situado entre una acequia, al oeste, y el barranco de Juliana, por levante ${ }^{10}$. El 3 de noviembre de 1196, Bernat de Godall vendió a Ramon de Xerta la algezira de Aguilen, un espacio rodeado por el Ebro, excepto por el lado oriental, donde se mencionan los honores de Arnau Garidell y Guillem Guid ${ }^{11}$. Por esta pieza, adyacente a la orilla, se pagaba una importante suma: 400 mazmudinas de oro al peso, lo que evidencia el valor en que era estimada.

El 10 de agosto de 1243, Arnau Aurícela y su esposa Elisenda vendieron a Andreu Berard un honor cultivado y yermo, con las cuevas existentes, con plantas y árboles, que tenían en Aguilen, que limitaba a poniente con el Ebro ${ }^{12}$. Cinco años más tarde, el mismo Andreu Berard lo revendía a Ramon Tons (Virgili et al., 2018: doc. 1132). Del paraje se precisa que estaba citraYberis, en el lugar llamado Coves de Guillem Eimeric, con las casas y las cuevas, la tierra cultivada y yerma, plantas, árboles, acequias y fuentes. La coincidencia de las dos piezas es incuestionable, pero al describir el límite occidental indica la presencia del Ebro y la algezira de Joan Arnau, que antes había sido de Albert de Xerta, tal vez un hijo del Ramon de Xerta que la había comprado en 1196, como se ha dicho. Ambas menciones se refieren, inequívocamente, a la misma algezira.

El honor comprado por Ramon de Tons debía tener una superficie considerable, ya que una vez en su poder delimitó parcelas que estableció a campesinos. Así, el 26 de noviembre de 1262, donó a perpetuidad a Bernat Martí dos suertes de tierra, cultivadas e incultas, con plantas y árboles, situadas en su manso de Coves, en Aguilen (Virgili et al., 2018: doc. 1241). En los límites figuran el Ebro, como siempre a occidente, la mencionada vía pública y la algezira de Joan Arnau (antes citada). A fines de 1266, Pere de Aguilar adquirió, en sendas compras, los derechos sobre tres suertes de tierra en Aguilen y Coves, citra Iberis, situadas entre el Ebro y el acantilado (rupibus) (Ibid.: docs. 1274, 1277). Se menciona una acequia de Joan Arnau, el poseedor de la algezira, que estaría situada seguramente al norte y, por tanto, dispuesta en perpendicular al río. Es plausible que la algezira, mencionada reiteradamente en esos documentos, corresponda a la tierra

este topónimo, ni en su forma latina, ni en la versión catalana (Ull del Llop, «Ojo del Lobo»). En el documento este lugar consta junto a la mención del prado, por lo que podría estar cerca, o incluso en él, haciendo referencia a una cavidad desde donde mana agua. Este es uno de los sentidos de la voz catalana ull, "ojo», análoga a la voz ullal, "colmillo", que en las tierras del Ebro se emplea para designar el lugar de nacimiento de agua subterránea (AlCOver \& MOLL, 1988: t. 10, 600, 605). La referencia documental, en ACA, OO. MM., Gran Priorat, Tortosa, códice 115, d. 229, f. 70v.

10. ACA, OO. MM., Gran Priorat, Tortosa, códice 115, d. 155, fs. 50v-51r.

11. ACA, OO. MM., Gran Priorat, Tortosa, códice 115, d. 159, f. 52r.

12. [...] honor cum omnibus covis que ibi sunt [...] apud Aguileyn (VIRGILI et al., 2018: doc. 1037). 
firme situada entre la acequia y el río. En diciembre de 1289, Berenguer Ferrer y su esposa Narbona, habitantes de Tortosa, vendieron una pieza de tierra campa, con plantas y árboles, que tenían junto a un honor que trabajaban a censo para el prior del cabildo, en Covas de Aguileyni, citra Iberis ${ }^{13}$; en uno de los lindes figura el roquedal (rupibus), por lo que su localización está clara.

Otros documentos del primer cuarto de la centuria siguiente confirman la ubicación del espacio de cultivo de Naguilen o Aguilen, que se extendía entre el roquedal donde estaban las cuevas y la orilla del Ebro, y cuyas piezas se distribuían entre una red de acequias. En agosto de 1301, Ferrer de Bas establecía a los hermanos Joan y Pere Franc en una pieza de tierra campa citra Iberis [...] in algira nostra ${ }^{14}$. En uno de los límites tenía la cequia vocata mare (madre) que se tenet cum via que itur apud Aldeyam, en otro, con otra acequia situada en la parte alta de un huerto del donador, y finalmente, con el Ebro mediante un camino vecinal. En 1306, el mismo Ferrer de Bas formalizaba un nuevo establecimiento, ahora a favor de Arnau Argençola, de una suerte y media de tierra campa en el mismo emplazamiento que el anterior, in algeira nostra ${ }^{15}$. Como antes, la parcela estaba situada entre la cequia vocata mare y el Ebro. Sin duda, la situación de este espacio, encajonado entre el río y las acequias, le confiere el carácter de isla (algira, algeira o algezira), y además se trata de la misma ya mencionada en los documentos del siglo XII.

En noviembre de 1311, el prior Bernat de Jardí, establecía al ya nombrado Arnau Argençola, habitador de Tortosa, dos suertes de tierra campa que limitaban con la cequia vocata mare y las garrigas del camino que conducía a L'Aldea ${ }^{16}$. Arnau Argençola, recordémoslo, había recibido unas tierras a censo de Ferrer de Bas, por lo que no se puede descartar que éste transfiriera las tierras que tenía en Aquilen a la sede de Tortosa, aunque no disponemos del documento que confirme este extremo. De lo que parece no haber duda es de que esta acequia, llamada madre, no es otra que la acequia mayor, el colector principal de una red de canales de drenaje para la expulsión de las aguas sobrantes del prado.

En 1326, Berenguer Ballester, ciudadano de Tortosa, establecía a Domènec Andreu, campesino de Tortosa, una pieza de tierra que tenía por el prior, en Aguilen ${ }^{17}$. Entre los límites figuran el roquedal (rupibus), una suerte de tierra que Guillem Bardina tenía del

13. Arxiu Capitular de Tortosa (ACT), caj. 53, Coves de Naguillem, etc., perg. s. n.

14. ACT, caj. 53, Coves de Naguillem, etc., perg. s. n.

15. ACT, caj. 53, Coves de Naguillem, etc., perg. s. n.

16. ACT, caj. 53, Coves de Naguillem, etc., perg. s. n.

17. ACT, caj. 53, Coves de Naguillem, etc., perg. s. n. 
prior, y un honor del citado Ferrer de Bas. En 1356, Arnau de Prat, como procurador del prior, establecía in enphiteosim ad bene laborandum a Berenguer Arnau, cordelero, habitante de Tortosa, dos porciones de tierra campa con plantas y árboles, in partita de Aguilleyn ${ }^{18}$. Los límites precisan la situación de estas piezas: confrontatas in cequia de la mare departin ab la alguira et in terra Petri d'Arenis et in roquis de Agileyn et in sorte que fuit Petri Ferrarii. No se puede descartar que Pere Ferrer fuera un hijo de Ferrer de Bas, el propietario que formalizaba establecimientos hacia el primer cuarto de la centuria. Otra vez la acequia mayor y el roquedal ayudan a situar este espacio de cultivo que se extendía entre el acantilado donde había las cuevas y la orilla del Ebro.

Todo parece indicar que Ramon Tons y Ferrer de Bas, así como la sede de Tortosa, eran propietarios de explotaciones que gestionaron mediante su parcelación en diversas tenencias, cuyos poseedores, que se mencionan directamente y en los límites, les pagaban censos. A lo largo de un siglo, lo que corresponde a tres generaciones, hemos contabilizado alrededor de treinta posesores distintos, una veintena de ellos en relación al honor de Ramon Tons, lo que indica un impulso del proceso de colonización y cultivo, en estas fechas centrales del siglo XIII, de la zona que se extendía a los pies del roquedal donde se abrían las cuevas hasta la orilla del Ebro. Poner en cultivo este sector exigió la construcción de una compleja red de canales de drenaje, articulada a partir de un colector central principal donde confluían el resto de las acequias.

$\mathrm{Al}$ sur, los documentos mencionan otro topónimo: Quint, o Quinto. En 1152, Ramon Berenguer IV hacía donación de un campo situado en prado de Quint a Pere Rajadell, quien lo cedió en testamento a la sede de Tortosa en $1163^{19}$. Un tal Zara, por su parte, recibió del conde un honor de 12 cuarteras de semilla (unos $30.000 \mathrm{~m}^{2}$ ), donde se recogían también 20 quintales de uva (vindemia), y otra pieza de tierra de dos cuarteras de siembra (5.000 $\mathrm{m}^{2}$ ) en ese lugar (Virgili, 1997: doc. 46). Asimismo, en 1170, Bonifaci y su esposa Mateda vendían a Ponç, obispo de Tortosa, un campo que tenían por donación condal en Quint (Ibid.: doc. 204); la parcela limitaba con el Ebro por poniente. En marzo de 1173, Guillem de Sant Cugat, uno de los tenentes documentado en los lindes de una de las piezas de tierra citadas, y su mujer empeñaban a Guerau Guasch un manso que tenía en Quint, situado entre la vía de Camarles y el Ebro, con una comba de Pere Oleguer al norte y la Pedrera en el sur, lo que significa que este manso estaría situado en el sector más meridional de la zona ${ }^{20}$. En sendas permutas realizadas por la encomienda del

18. ACT, caj. 53, Coves de Naguillem, etc., perg. s. n.

19. El primer documento lo conocemos solo a través de un resumen contenido en los índices del inventario del ACT; véase VirgILI (1997: doc. 32). El testamento, en VirGILI (1997: doc. 134).

20. ACA, OO. MM., Gran Priorat, Tortosa, códice 115, d. 164, f. 53. 
Temple se mencionan unos campos que lindaban con el Ebro por occidente, por tanto, situados en la orilla (Pagarolas, 1984: docs. 68, 89), y el prado por levante; uno de ellos limitaba con la cequia del prato al este y otra acequia al norte. La disposición de la acequia del prado, el colector principal de una red de drenaje, era norte-sur, a la cual embocaba la otra, en dirección oeste-este.

Entre el prado de Quint y Burjassénia los templarios impulsaron el cultivo de la tierra mediante establecimientos enfitéuticos. En diciembre de 1238, se concedía a Guillem de Aguiló y Pereta un manso (ad laborandum et excolendum) situado entre los términos de Burjassénia y Rocacorba, por lo tanto, en el prado (Pagarolas, 1999b: doc. 49). A finales de agosto de 1243, Pere de Montpalau, el comendador de Tortosa, donaba a censo a Guillem de Blanes y Ramon d'Arany un honor, parte en cultivo y parte yermo, situado junto a la viña que la orden tenía en el prado, y lindaba con la vía que unía Burjassénia y el prado (Ibid.: doc. 61).

A tenor de la superficie del espacio, los contratos formalizados parecen pocos. Es muy probable que los campos adquiridos por la encomienda incluyeran ya los campesinos que los explotaban a censo, por lo que no era necesaria una nueva contratación. Además, las referencias documentales revelan una extensa zona de prado, seguramente inculta, destinada a pastos para el ganado.

Sin lugar a dudas, estos documentos remiten a un espacio de ribera adyacente al margen del Ebro, lindero a poniente de muchas de las parcelas documentadas. La red de acequias de drenaje y las menciones al prado indican la existencia de un área inundable que sería objeto de acondicionamiento para impulsar los trabajos de colonización ${ }^{21}$.

En cuanto a los cultivos y aprovechamientos de las parcelas, la mayor parte son calificadas de tierra y campos (más de treinta menciones); hay referencias vagas a un par de viñas; ya en dirección a Burjassénia destaca un gran viñedo del Temple. Más tardíamente figuran unos olivares y un par de huertos. Todo parece indicar, pues, que al principio era un espacio uniforme de tierra campa, inculto en buena parte, o destinado eventual, pero no necesariamente, a la siembra de cereales. Por lo que se deduce de los censos, este se-

21. Estas acequias están bien documentadas en ambas orillas del Ebro. MARTí y NEGRE (2015) y NEGRE (2015) interpretan que se trataba de acequias de largo recorrido (entre doce y catorce kilómetros) vinculadas a la madîna y al Estado. Esta propuesta ha sido desmentida por KIRCHNER y VIRGILI (2019): el río Ebro jamás fue captado para derivar agua hacia canales en época andalusí ni bajo dominio feudal, hasta mediados del siglo xIV; los espacios colonizados eran discontinuos y las acequias de drenaje cubrían solo estos perímetros, sin unirlos, por lo que los canales en ningún caso alcanzaban distancias superiores a un kilómetro. 
ría el destino preferente a partir de entonces, según los intereses de los conquistadores. La existencia de un molino y de unos silos cercanos avala esta percepción. También se impone, en algunos casos, el cultivo de la viña, a tenor de una condición que establecía al receptor la obligación de plantar vides en la cuarta parte de la superficie de una parcela (vineam vivificatam), bajo penalización de 60 sueldos en caso de incumplimiento ${ }^{22}$. Los receptores de las suertes de tierra, por otra parte, tenían que mantener la red de acequias en condiciones (condirectas). Las parcelas se distribuían y se ordenaban a partir de los ejes que formaban las acequias y el propio río, que era su límite occidental. En Quint, los huertos estaban situados sobre la plataforma sedimentaria del barranco, formando parcelas pequeñas e irregulares regadas con el agua de pozos de noria (10-14 metros de profundidad). El resto del espacio estaba formado por zonas de marjal y prado, con ínsulas, garrigas, pastos y la vegetación de ribera propia del curso bajo fluvial.

\section{FIGURA 2}

El prado entre Aguilen y Quin-la Pedrera: espacios de colonización

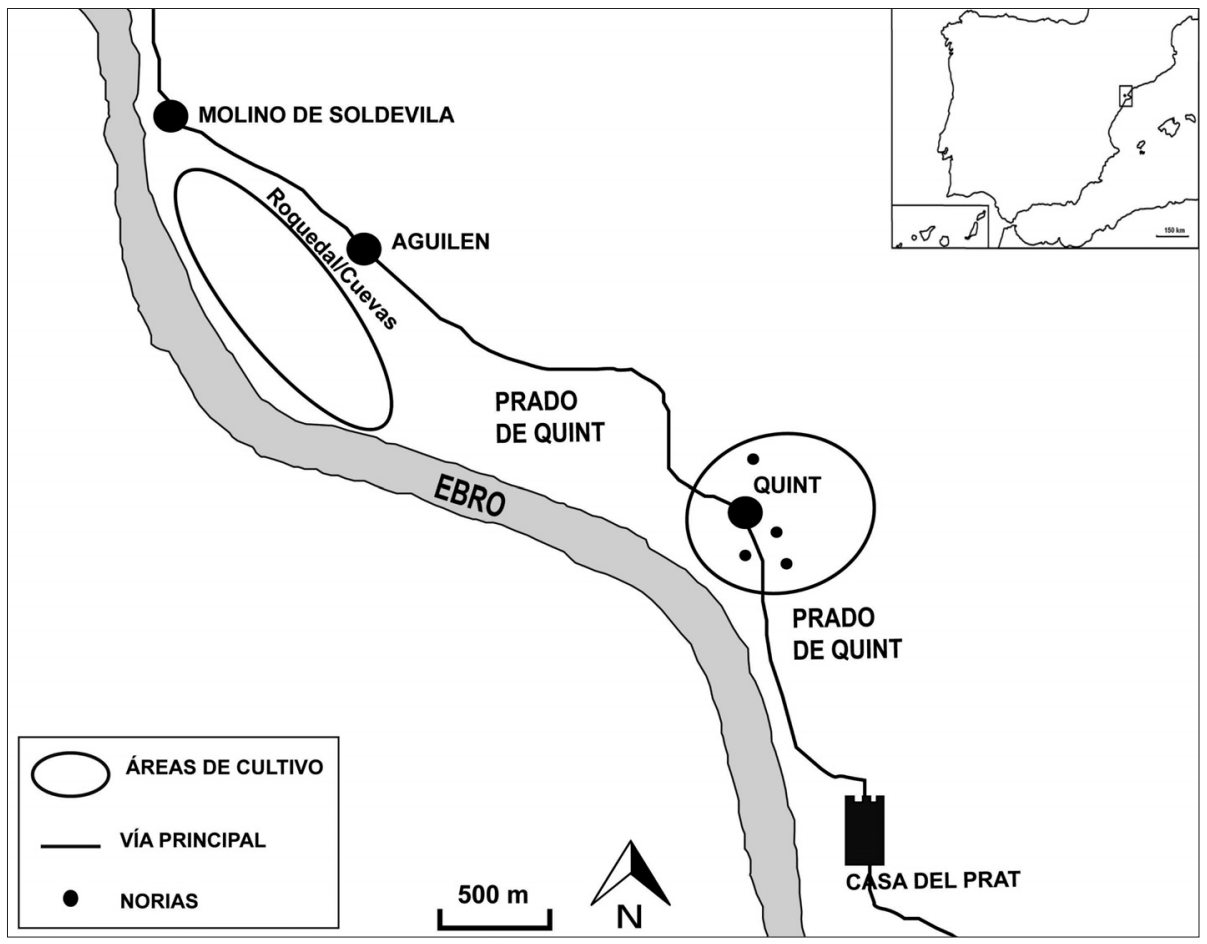

Fuente: A. Virgili.

22. ACT, caj. 53, Coves de Naguillem, etc., perg. s. n. 


\subsection{El molino de Soldevila}

Como hemos visto, la donación de Ramon de Montcada incluía un molino. La documentación de los siglos XII y XIII menciona una zona de molienda en la Pedrera, el área más meridional del sector. Sin embargo, no existe ningún resto, recuerdo, ni otro indicio material de la existencia de molinos en ese lugar, ni captaciones, ni canales de transporte de agua, ni tan siquiera un edificio para albergar el obrador. Tampoco existe ningún elemento natural para abastecerlo de agua. En cambio, la descripción documental concuerda absolutamente con la situación del molino llamado de Soldevila.

El origen de esta posesión se encuentra en la donación que, en octubre de 1172, Oller de Tamarit efectuó a favor de Ramon de Montcada, de un campo con el molino, el casal, la canalización (caput rego), las aguas y el prado en la Pedrera ${ }^{23}$; el conjunto limitaba al norte con un campo de Alegret, al sur y levante con la montaña y por poniente con el Ebro. Los Montcada traspasaron sus derechos sobre el molino a los templarios (Pagarolas, 1984: doc. 63), y a mediados de diciembre de 1176, Radulf Barbablanca, un genovés que había participado en la conquista de Tortosa, vendía a la orden todos los derechos que los Montcada le habían concedido sobre dicho molino por 50 sueldos (Ibíd.: doc. 64). Se trata, inequívocamente, del mismo inmueble, a pesar de que los lindes puedan diferir ligeramente: limitaba al norte con una acequia y un aguazal (palud), al sur con un campo, al este con el roquedal (in rocha), y al poniente con el Ebro. El molino se menciona de nuevo en 1185 entre los bienes de la orden del Temple, en el sector del prado de Quint (Virgili, 1997: doc. 383; Pagarolas, 1984: doc. 88).

El molino de Soldevila, hoy desaparecido, ocupaba el espacio de la estación de bombeo, construida en 1989, para abastecer de agua a Tarragona; en sus inmediaciones se localizaron unos silos para almacenar grano (Arbeloa, 1997). Gracias a los testimonios orales hemos conocido el emplazamiento de este antiguo molino harinero y el sistema que suministraba el agua para su accionamiento. Era un sistema modesto, que se iniciaba en la aportación de dos manantiales (ullals) cercanos, cuya agua era conducida por una acequia hasta el molino ${ }^{24}$. El cárcavo echaba las aguas directamente al Ebro.

23. ACA, OO. MM., Gran Priorat, Tortosa, códice 116, d. 155, f. 51r.

24. La capacidad de molienda del molino de Soldevila era escasa debido al caudal irregular, la escasa pendiente y la ausencia de una balsa para acumular agua y aumentar la presión. 


\section{LA COLONIZACIÓN DE BURJASSÉNIA}

Los primeros impulsos en este sentido los protagonizaron los Montcada, los primeros señores del lugar, cuando en 1167 dieron a censo, a Pere de Vall y a su esposa, una suerte de tierra con un huerto, un pozo y una viña ${ }^{25}$. Limitaba al norte con otra viña, al sur con la vía de L'Aldea a Amposta, al este con un arrahal antiguo y al oeste con una madriguera de conejos (cavo de conills). Se establecía un censo evaluado en la mitad de la cosecha, pero el donador tenía que aportar la mitad de la semilla para la siembra. El receptor, a su vez, tenía que romper cuanta tierra pudiera (arrabacetis tantam terram quam tradere poteritis), de la que sólo libraría la tasca (una onceava parte). El contrato pone de manifiesto que grava de forma muy onerosa la tierra cultivada; al contrario, los censos de las tierras arrancadas al yermo eran mucho más módicos, con la clara intención, por parte de los señores, de priorizar e incentivar la puesta en cultivo de espacios hasta entonces incultos.

En julio de 1184, cuando ya se había efectuado la donación al Temple, Ramon de Montcada y su mujer infeudaban a Ramon de Centelles el mansum de Borgasenia, situado justo al sur de la vía de L'Aldea (coincide totalmente con el emplazamiento actual) ${ }^{26}$; al sur tenía ya el prado, al levante una acequia abierta por los propios concedentes y al poniente el honor de Ambròs de Santponç, sin duda el mismo que se documenta una década después, cuando sus herederos toman posesión del inmueble ${ }^{27}$. El concedente ordena una cláusula en términos muy parecidos a la del documento anterior para promover la roturación del prado hacia el sur: ut parte vero meridie laboretis de prato quantum laborare potueritis.

En febrero de 1207, Berenguer de Tornamira, en representación de Ramon de Montcada, donaba a censo al matrimonio formado por Domènec y Maria seis piezas de tierra en el lugar llamado castrum de Borgacenia, y cerca de la vía de L'Aldea, según se expresa en los lindes de las parcelas ${ }^{28}$. La concesión incluía un solar para construir una casa en el núcleo y un espacio para huerto delante de una alberca ( $z a p h a r e g$ ), libre de censo. Los límites de las parcelas muestran el paisaje del prado: un camino que conducía al prado

25. ACA, OO. MM., Gran Priorat, Tortosa, códice 115, d. 44, f. 14.

26. Es posible que Ramon de Montcada conservara algunos derechos en Burjassénia que tal vez acabaran en poder templario, a pesar de no conservarse el documento. Solo así se entiende que las concesiones de los Montcada figuren en los archivos de la orden, siguiendo la costumbre de entregar las escrituras redactadas con anterioridad al traspaso del dominio.

27. Los documentos en ACA, OO. MM., Gran Priorat, Tortosa, códice 115, d. 53, f. 17, y VIRGILI (2001a: doc. 553).

28. ACA, OO. MM., Gran Priorat, Tortosa, códice 115, d. 46, fs. 14v-15r. 
(dirección norte-sur), in aqua que pergit Arnaldo de Osona, tal vez en referencia a una acequia, el término de L'Aldea (a levante), garrigas, y también se mencionan lagunas o charcas en varias ocasiones (basas y basas subiranas, situadas en la parte alta, para distinguirlas de otras situadas en la parte baja).

El primer establecimiento de la orden del Temple, fechado en julio de 1186, se realizó sobre un manso cercano a L'Aldea y Burjassénia a favor de Berenguer de Vic y su familia (Pagarolas, 1999a: doc. 208) ${ }^{29}$. A partir de entonces, se formalizaron diversos contratos, en 1216, 1226, 1234, 1238 y 1239 (Ibíd.: docs. 3, 29, 43, 48, 49, 50). Estos no suponían la constitución de nuevos mansos o la roturación de nuevas parcelas, sino su renovación o el relevo de los propietarios sobre explotaciones en cultivo.

El 15 de enero de 1240, el Temple concedía un establecimiento múltiple -semejante a una confirmación- sobre todos los honores que tenía infra terminos de Burjassénia (Pagarolas, 1999b: doc. 51).Y en la misma fecha, subscribía una serie de contratos con algunos de los protagonistas del documento anterior (Ibíd.: docs. 52, 53, 54, 55). Uno de ellos fue una renovación ante la situación generada por la defunción del titular (Ibid.: doc. 55). En enero de 1243, la orden establecía a Joan Bonmassip y a su familia en una viña situada en Burjassénia, por encima del camino, sicut est conclusa et terminata, con los árboles y plantas existentes (Ibid.: doc. 60). Los lindes de estas parcelas reproducen los nombres de los mismos propietarios, por lo que sin duda formaban un espacio agrario homogéneo. El programa de establecimientos agrarios coincide cronológicamente, en buena parte, con la ampliación y la consolidación de Burjassénia como núcleo residencial.

En efecto, entre 1240 y 1260, la orden del Temple de Tortosa llevó a cabo un programa para afianzar el asentamiento de Burjassénia y convertirlo en un núcleo urbano de una cierta envergadura, centro de residencia de buena parte de los campesinos que trabajaban los predios del sector, mediante la concesión de viviendas y solares a condición de construir casas y corrales: quandam plateam [...] ad construendum domos et currallem; quandam plateam [...] sicut fixuris suis concluditur et ambitur longue lateque, ad faciendum, construendum seu edificandum (Pagarolas, 1999b: docs. 56, 61, 69, 77, 79, 80, 90, 106). Los conceptos castlario y castrum, así como la existencia de un muro y la torre, indican un inicial núcleo fortificado (castrum et turrim Boryacenie, ad faciendum, construendum, reparandum, rehedificandum seu etiam agendum), aunque la función residencial se tiene que relacionar con el proceso de colonización agraria del lugar.

29. El mal estado del manuscrito impide conocer más detalles acerca de esta concesión; el editor aporta un resumen, sin la transcripción. 
FIGURA 3

Espacios de colonización del prado de Burjassénia

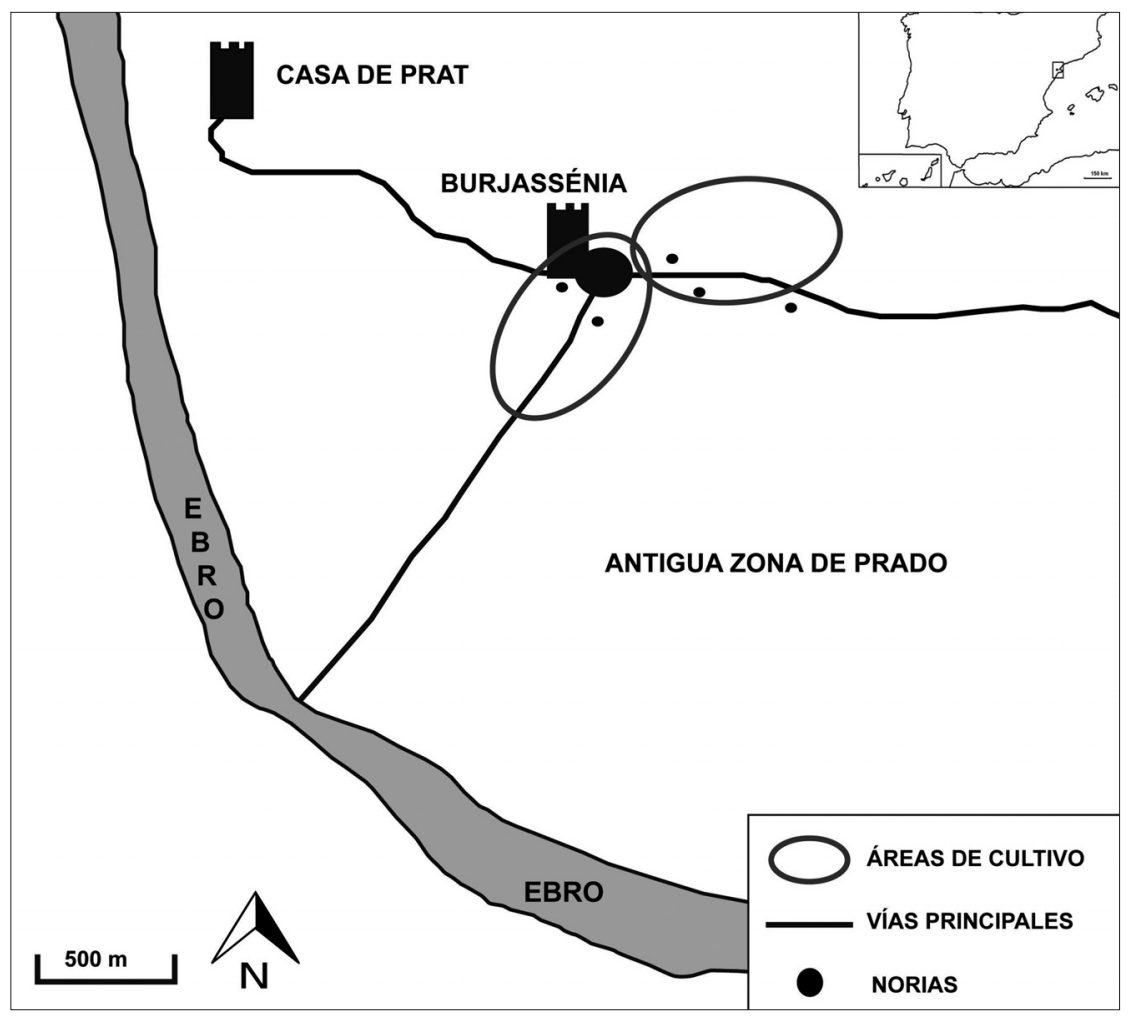

Fuente: A. Virgili.

A lo largo de un siglo se documenta en Burjassénia y su término la presencia de entre treinta y cinco y cuarenta cabezas de familia, con un mínimo de una docena de hogares, entre 1240 y 1263, lo que da una idea de su magnitud. Entre estas fechas, pues, se consolidó el asentamiento cristiano que inicialmente estaba constituido por unas pocas casas dotadas de elementos fortificados: una torre, mencionada en 1196, y un muro. Por las indicaciones de las lindes, el parcelario de cultivo era adyacente al centro residencial, y a ambos lados del camino.

Entre los cultivos, se observa un claro predominio de los viñedos, con 22 menciones; los documentos revelan que la orden tenía en su poder un gran viñedo rodeado por una cerca del que se iban segregando parcelas previamente amojonadas (fixuratas) para establecer posteriormente. En su conjunto, las parcelas de viña objeto de contrato limitaban a menudo con otras viñas formando agrupaciones homogéneas de este cultivo ( $\mathrm{Pa}$ garolas, 1999b: docs. 52, 53, 54). Se mencionan diez huertos, también lindantes unos con 
otros (Ibid.: doc. 48), asociados a aljibes y albercas para el regadío ${ }^{30}$. En la actualidad se conservan pozos con norias, dos en el núcleo de Burjassénia y otros en las inmediaciones, que podrían corresponder a los instantes iniciales de la puesta en cultivo de este espacio, si nos remitimos al citado perímetro de huertos.

\section{LA EXPLOTACIÓN GANADERA DEL PRADO}

Las referencias al prado son constantes en los primeros documentos referidos a Quint y Burjassénia, en especial cuando se concedieron los primeros establecimientos que tenían por objeto ampliar la superficie de cultivo a su costa. La vía que conducía al prado, la existencia de lagunas y acequias, así como de espacios de garriga, muestran nítidamente este paisaje. La actividad ganadera que se observa en todos los lugares del prado se percibe también, cómo no, en este sector. Como hemos visto, abundan las referencias a corrales, y también menciones a dehesas, cuyo fin era alimentar a los propios rebaños, pero también cobrar tasas por la cesión de derechos de herbaje.

Conocemos la cabaña de la encomienda de Tortosa gracias a un inventario realizado en mayo de 1289 que pone de relieve la cantidad y la variedad del ganado en su poder: 3 mulos y 4 mulas, 18 asnos, 15 yeguas, 30 bueyes de labranza, 12 novillos, 48 vacas y 2 toros, 60 cerdos, 211 ovejas, 15 marranos y 26 carneros, 11 cabras, 8 puercos, y varias cabezas más, entre rocines y caballos (Pagarolas, 1999b: doc. 162). Hemos de tener en cuenta que la tenencia del prado incluía también las tierras de Burjassénia, con sus cotos y dehesas para el ganado.

Los pleitos originados por los conflictos derivados de la práctica ganadera revelan aún más la importancia de esta actividad. El acceso a los pastos del prado de Quint y Burjassénia figura en la base de las incidencias que se produjeron ya desde fines del siglo XII. En julio de 1194, el rey Alfonso el Casto expedía una carta donde manifestaba tener conocimiento de las quejas reiteradas del abad y los frailes del monasterio de Santes Creus ante los templarios, porque la orden impedía la entrada de sus rebaños en los prados de Quint, a pesar de los derechos adquiridos tiempo atrás por el cenobio; y, puesto que la milicia hacía caso omiso a tales reclamaciones, el monarca ordenó que no se podía impedir el disfrute de los pastos, por lo que esperaba no recibir más quejas al respecto (Carreras, 1992: 236). Los incidentes más graves, sin embargo, se produjeron a finales del siglo XIII a causa de los enfrentamientos entre la milicia del Temple y la ciudad de Tortosa, en representación de los intereses de sus ciudadanos. En rigor, este conflicto se ins-

30. ACA, OO. MM., Gran Priorat, Tortosa, códice 115, d. 46, fs. 14v-15r; Pagarolas (1984: 43). 
cribe en un contexto general de tensiones intermitentes generadas por el creciente poder señorial en Tortosa y su término, en detrimento del poder real y sus prerrogativas, expresadas en los privilegios otorgados por el conde Ramon Berenguer IV a favor de los ciudadanos en las cartas de población de 1148 y 1149.

A partir de las dos últimas décadas del siglo XII, el poder de la orden del Temple se había afianzado en Tortosa, especialmente a raíz de la donación real, en 1182, confirmada por Pedro el Católico en 1202 (Pagarolas, 1984: 139-144; Pagarolas, 1999a: 157-164; Fabregat, 2006: 75-76). Al ejercicio de la señoría se añadía el considerable dominio patrimonial obtenido desde el mismo momento de la conquista, lo que desató la airada reacción de los sectores ciudadanos al ver erosionados sus privilegios, contenidos en la carta puebla condal. Las franquicias lesionadas eran, ante todo, las derivadas del libre acceso a los recursos comunales en el término general de la ciudad de Tortosa (yermos, campos, montañas, aguas, pastos, etc.) y, por tanto, el derecho de presura sobre los yermos y el disfrute de los pastos (Fabregat, 2006).

Los litigios dieron lugar a numerosas composiciones y sentencias, la mayoría, favorables a los intereses de los sectores urbanos, que confluyeron en la redacción de las Costums de Tortosa (Ordenamientos) aprobadas el 28 de noviembre de 1272 (Massip, 1996). Las Costums establecían el libre acceso de los ciudadanos de Tortosa a los comunales, tierras yermas, bosques y pastos, en el término de Tortosa, a la vez que prohibían a los señores la reserva de cotos, dehesas y boalares con usos privativos.

En septiembre de 1294, el Temple y la monarquía, con Jaime II el Justo al frente, formalizaron una permuta por la cual la milicia devolvía Tortosa a la Corona (Pagarolas, 1999b: doc. 172) ${ }^{31}$. No obstante, la orden retenía en alodio las heredades patrimoniales propias en torres, boalares, honores, olivares, etc., lo que daba a entender la importancia que para ella tenía la ganadería, al tener garantizada, por concesión real, in perpetuum, in terminis Dertuse, pascua et ademprivia (Ibid.: doc. 173). Como se ha indicado ya, en la relación de bienes patrimoniales figuraba el conjunto formado por el prado de Quint y Burjassénia ${ }^{32}$.

31. Sobre los motivos de esta decisión, véanse Pagarolas (1998, 1999a: 243-249) y Fabregat (2006: 147-149).

32. Sobre las reservas patrimoniales templarias y los conflictos posteriores, véanse PAGAROLAS (1998, 1999a: 249-253) y FABREGAT (2006: 151-158). 
Desde la ciudad se interpretó que con la permuta y la recuperación de Tortosa por la monarquía las dehesas y los pastos eran de acceso libre, a pesar de la reserva templaria. Así, los hombres de Tortosa introdujeron su ganado en los cotos de la milicia en Quint y Burjassénia (Pagarolas, 1999b: doc. 180), y la orden exigió a los representantes del rey una reparación de los daños y perjuicios que dichas acciones habían ocasionado en esos lugares. El documento está fechado el 29 de noviembre de 1294, inmediatamente después de ejecutarse la permuta. Este es el contexto que explica el largo y duro contencioso que enfrentó a los ciudadanos de Tortosa, con sus representantes al frente de las principales magistraturas, con la milicia del Temple por el acceso a los pastos de las dehesas y cotos del prado de Quint y Burjassénia ${ }^{33}$.

En 1295, la orden planteaba la misma reivindicación sobre Burjassénia, el manso del prado, Quint y Aguilen, en las tierras, posesiones, prado, garrigas, dehesas, olivos y demás pertenencias (Pagarolas, 1999b: doc. 182). Las tensiones fueron constantes durante el último lustro del siglo XIII, ya por la irrupción de los hombres de Tortosa con su ganado, ya por causa de la persecución y detención de emisarios de la orden en defensa de sus intereses (Ibid.: docs. 185, 191, 192, 193, 195, 196, 197, 198, 199, 200).

Ante la gravedad de la situación, el rey, Jaime II, encargó al obispo de Tortosa, Arnau de Jardí, dirimir el contencioso y redactar una sentencia firme y definitiva al pleito. En la carta, fechada el 8 de diciembre de 1297, parecía reconocer inicialmente los derechos de la milicia; más aún cuando en una misiva posterior prohibía a los ciudadanos de Tortosa la entrada de rebaños en Burjassénia (Fabregat, 2006: 160).

Sin embargo, el resultado final fue otro. La sentencia emitida el 28 de mayo de 1299, y ejecutada en 1304, establecía el acceso libre de los habitantes de Tortosa a los comunales y la prohibición de acotar los pastos con fines privativos, según estipulaba la carta de población de 1149 y ratificaban las Costums de Tortosa ${ }^{34}$. Así, el Temple no podía evitar la entrada de ganado ajeno ni ejercer el derecho de carnaje. El veredicto creó jurisprudencia, y sus disposiciones fueron invocadas y aplicadas en otros lugares del término general de Tortosa (Fabregat, 2006: 168-171).

33. FabRegat (2006: 151-158) expone con todo detalle el desarrollo del conflicto, así como los litigios y pleitos que suscitó.

34. Rúbrica 2: De les pastures e del bovatge de la ciutat de Tortosa, ordenanza 1.2.1.: Tot lo bestiar dels ciutadans o dels habitadors de Tortosa o de sos térmens pot jaure e estar e pasturar francament e quitia, dins los térmens de la ciutat, e pasturar tro als laurats e usar. Sens carnàgie e herbàgie e tota servitut; ordenanza 1.2.2.: Seynors ne cavaylers, clergues ne religiosos, ne altres persones, no poden fer vedats en alcun loch dins e'l terme de Tortosa als ciutadans ne als hòmens de Tortosa (MASsIP, 1996: 17). 
Las escrituras generadas por estos pleitos ponen de relieve, por un lado, la violencia que caracterizó la irrupción de los ciudadanos de Tortosa en los pastos de Burjassénia, al describir cabalgadas de gente armada profiriendo amenazas a los servidores de la milicia y arengando a los pastores a desobedecer los mandatos; y por otro, muestran las dimensiones que podía alcanzar la cabaña, como las más de mil trescientas cabezas de un rebaño de ovejas y cabras de un tal Matalconill ${ }^{35}$.

\section{CONCLUSIONES}

Las investigaciones más recientes muestran que la conquista cristiana de al-Ándalus en todo su alcance, cronológico y geográfico, supuso una ruptura sin paliativos del orden político y social anterior al producir un impacto de gran alcance sobre la población y el paisaje. La consolidación de las conquistas requería canalizar recursos humanos hacia las regiones ocupadas con relación a los inmediatos procesos de repartimiento. Las fuentes escritas que genera la conquista revelan que cientos de familias emigraron de sus lugares de origen para asentarse en las nuevas tierras, y cabe suponer que su visibilidad representa una parte no mayoritaria de las que realmente lo hicieron. Parece indiscutible que este fenómeno migratorio es la respuesta y, a la vez, la alternativa a uno de los efectos de la conquista: el desalojo de la población nativa, parcial o total, en algunos casos, de los territorios que habían ocupado durante generaciones, una dinámica común a los procesos de conquista (Day, 2006). Los conquistadores impusieron nuevas pautas agrarias, en función de sus necesidades, que modificaron muy sustancialmente los paisajes existentes, como se ha indicado. Carece de sentido, en definitiva, plantear la conquista en términos de continuidad sobre la base del mantenimiento de la población y de las estructuras agrarias que la sostenían.

Los casos estudiados en la región del curso bajo del Ebro en el prado de Tortosa muestran claramente las consecuencias reales de la conquista. Entre las decenas de documentos estudiados no existe ni una sola mención de los antiguos poseedores andalusíes. En cambio, revelan el asentamiento de familias cristianas que recibían tierra a condición de poner en cultivo amplias superficies de baldío hasta entonces incultas, aunque sujetas a la explotación de recursos naturales, tales como pastos, caza, pesca o recolección.

35. La cabalgada encabezada por el notario Llorenç Cima en septiembre de 1297 estaba compuesta por más de veinte personas; en cuanto a los rebaños de Matalconill, dice textualmente que estaban formados por pus de mil CCC cabeçes entre cabrú e de lana, sia entrat furtívolament [...] (PAGAROLAS, 1999b: docs. 191, 192). 
Los aspectos más relevantes de esta investigación es que se ha centrado en un espacio deltaico de una gran superficie sujeto a cambios morfológicos por la acción del Ebro. Una documentación abundante y prolija en detalles permite describir el paisaje y reconstruir los procesos de colonización con gran precisión. Conocemos los procedimientos empleados: jurídicos (establecimientos enfitéuticos), físicos (roturar yermos), las cargas impuestas (rentas en torno a la cuarta parte de la cosecha, y el diezmo y la primicia de la Iglesia), y los resultados: la formación de núcleos de población y la construcción de parcelarios de cultivo en sus entornos. Una limitación importante es la ausencia de datos relativos a la superficie cultivada. Los documentos se expresan en términos vagos e inconcretos: los cultivadores tenían que romper tanta tierra como pudieran. Por otro lado, los espacios estudiados han sido modernamente convertidos en grandes extensiones de arrozal. De los parcelarios tradicionales, a menudo fosilizados y perceptibles en la cartografía, no resta ninguna traza. En este sentido, la información textual suple este inconveniente.

El estudio ha confirmado, a su vez, que las redes de acequias no partían de captaciones en el Ebro para irrigar huertas y campos, sino justo lo contrario: eran canalizaciones con la finalidad de acondicionar espacios de ribera fluvial, extensas zonas húmedas que, ni en época andalusí ni tras la conquista fueron áreas marginales. Los grupos humanos se afanaron siempre en aprovechar los recursos que generaban, como pone de relieve el interés de los señores jurisdiccionales en monopolizar todos los derechos inherentes a su disfrute, y el afán de los ganaderos en acceder a los pastos.

Los trabajos de roturación dieron lugar a la construcción de varios parcelarios discontinuos situados en zonas ganadas al prado. En algunos sectores, como en Aguilen y Quint, se drenó el terreno mediante acequias. En Burjassénia, los espacios de cultivo ocupaban los alrededores del núcleo de población concentrada, que se desarrolló y amplió a raíz de la conquista, y también en los márgenes de los caminos. La producción se orientó de forma preferente hacia cultivos extensivos de cereal o especulativos, como la viña, de amplio consumo en la ciudad de Tortosa, convertida en el principal foco receptor de inmigrantes. También se han documentado espacios de huerta, formados por pequeños huertos contiguos, regados mediante pozos con norias para elevar el agua.

En los intersticios de estos parcelarios y en los sectores de la llanura deltaica más cercanos al Ebro se extendían todavía grandes superficies de prado. Lo que en época andalusí pudo ser un espacio abierto y de acceso sin restricciones a los pastos, la encomienda del Temple pretendió explotarlo para usos privativos de su cabaña, mediante la formación de dehesas y cotos, o gravando la cesión de las hierbas. Esta política originó duras disputas desde un principio. Más allá del resultado de las disposiciones reales y las sen- 
tencias que originaron, estas controversias ilustran la riqueza de estos espacios como pastos y la importancia que la ganadería adquirió a raíz de la conquista, sin duda, una herencia del pasado andalusí. Todo ello se refleja aún en la toponimia, a pesar de las profundas alteraciones en el paisaje: diversos caminos del lugar conservan el nombre de lligallo, voz utilizada en la región para designar a las vías pecuarias.

\section{AGRADECIMIENTOS}

Antoni Virgili pertenece o ha participado en los siguientes proyectos: SGR «Arqueologia Agrària de l'Edat Mitjana» (ARAEM), 2017, SGR, 1073 (AGAUR); proyectos: «Órdenes agrarios y conquistas ibéricas (siglos XII-XVI): Estudios desde la arqueología histórica»: HAR2017-82157-P (MINECO), y «De Turtusa a Tortosa: Ciutat i espais agraris abans i després de la conquista cristiana (segles X-XIII)» (Direcció General del Patrimoni Cultural, Generalitat de Catalunya).

Agradezco los comentarios de Helena Kirchner y Antoni Ferrer (Universitat Autònoma de Barcelona) sobre el texto original. A Montserrat Muntané la corrección. A Montserrat Rovira y Marina Mateu su contribución técnica en la cartografía. Los comentarios, indicaciones y sugerencias de los evaluadores de la revista Historia Agraria han contribuido a mejorar muy considerablemente el texto. Yo soy, sin embargo, el único responsable de los defectos que pueda contener.

\section{REFERENCIAS}

Alcover, A. M. \& Moll, F. DE B. (1988). Diccionari català-valencià-balear. Palma de Mallorca: Moll.

Alsina, C., Feliu, G. \& Marquet, Ll. (1990). Pesos, mides i mesures dels Països Catalans. Barcelona: Curial.

ArbeloA, J.V. M. (1997). Localitzades tres noves sitges prop de Tortosa. Nous Col-loquis, (1), 29-32.

Ballesteros, P. et al. (2010). Por una arqueología agraria de las sociedades medievales hispánicas: Propuesta de un protocolo de investigación. En H. KirChNer (Ed.), Por una arqueología agraria: Perspectivas de investigación sobre espacios de cultivo en las sociedades medievales hispánicas (pp. 185-202). Oxford: Archeopress. (BAR International Series, 2062).

BARTLETT, R. (2003). La formación de Europa: Conquista, colonización y cambio cultural, 950-1350.Valencia: Universitat de València. [Trad. esp. de: The Making of Europe: 
Conquest, Colonization and Cultural Change, 950-1350. Princeton: Princeton University Press, 1993.]

CARmona, M. A. (2018). La transformación de los paisajes rurales en el valle del Guadalquivir tras la conquista cristiana (siglo XIII). En J.ToRRó \& E. GuINOT (Eds.), Trigo y ovejas: El impacto de las conquistas en los paisajes andalusíes (siglos XI-XVI) (pp. 93117). Valencia: Universitat de València.

CARreras, A. (1992). El monestir de Santes Creus, 1150-1200. 2 vols. Vol.: Explotació $i$ administració: Apèndix documental i indexs. Valls: Institut d'Estudis Vallencs.

Clemente, J. (2018). Modelos agrarios en Extremadura: Entre el islam y occidente. En J. TorRó \& E. GuINOT (Eds.), Trigo y ovejas: El impacto de las conquistas en los paisajes andalusíes (siglos XI-XVI) (pp. 77-92). Valencia: Universitat de València.

DAy, D. (2006). Conquista: Una nueva historia del mundo moderno. Barcelona: Crítica.

Díaz Sierra, I., López García, E. \& Retamero, F. (2018). Los campos de los moriscos y de los castellanos en Igualeja, Serranía de Ronda (Málaga), siglo XVI. En J. TorRó \& E. GuINoT (Eds.), Trigo y ovejas: El impacto de las conquistas en los paisajes andalusies (siglos XI-XVI) (pp. 257-282). Valencia: Universitat de València.

FABREgAT, E. (2006). Burgesos contra senyors: La lluita per la terra a Tortosa (1148-1299). Tortosa: Arxiu Comarcal de les Terres de l'Ebre, Consell Comarcal del Baix Ebre.

Font Rius, J. M. (1969). Cartas de población y franquicias de Cataluña. Barcelona: Consejo Superior de Investigaciones Científicas.

Fuguet, J. (1998). Fortificacions menors i altre patrimoni retingut pels templers a Tortosa després de la permuta de 1294. Anuario de Estudios Medievales, (28), 293-309.

García-ConTreras, G. (2018). Feudalización y cambio ecológico en el sector oriental de la Extremadura castellana: Poblamiento y paisaje en los territorios de Atienza, Sigüenza y Molina (siglos XI-XIII). En J. TorRó \& E. GuINOT (Eds.), Trigo y ovejas: El impacto de las conquistas en los paisajes andalusies (siglos XI-XVI) (pp. 51-76). Valencia: Universitat de València.

García-Contreras, G. (2019). Ay Malos Pasos et Tremedales: El agua como condicionante del poblamiento medieval del señorío episcopal de Sigüenza (Guadalajara). Riparia, (5), 167-209.

GLICK, T. F. (2007). Paisajes de conquista: Cambio cultural y geográfico en la España medieval. Valencia: Universitat de València.

GONZÁlEZVILlAESCUSA, R. \& KIRCHNER, H. (1997). La construcció d'un espai agrari drenat andalusí al hawz de la Madîna de Yabîsa: Anàlisi morfològica, documental i arqueològica del Pla de Vila. En M. BARCELó (Coord.), El curs de les aigües:Treballs sobre els pagesos deYabisa (290-633 H/902-1235 dC) (pp. 65-96). Eivissa: Consell Insular d'Eivissa i Formentera. (Quaderns d'Arqueologia Pitiüsa, 3).

Guinot, E. (2003). El desplegament feudal sobre el País Valencià: Repartiment i colonització a l'horta de València: Montcada (1239-1246). En M. BARCELÓ, G. FeLIU, A. 
Furió, M. Miquel \& J. Sobrequés (Eds.), El feudalisme comptat $i$ debatut: Formació $i$ expansió del feudalisme català (pp. 361-388). Valencia: Universitat de València. GuINot, E. (2018). La construcción de nuevos espacios agrarios en el siglo XIII: Repartimientos y parcelarios de fundación en el Reino de Valencia: Puçol y Vilafamés. En J. TORRó \& E. GUINOT (Eds.), Trigo y ovejas: El impacto de las conquistas en los paisajes andalusíes (siglos XI-XVI) (pp. 119-160). Valencia: Universitat de València.

Guinot, E. \& SELMA, S. (2012). La construcción del paisaje en una huerta feudal: La Sèquia Major de Vila-Real (siglos XIII-Xv). En J. ToRRó \& E. GuINOT (Eds.), Hidráulica agraria y sociedad feudal: Prácticas, técnicas, espacios (pp. 103-146).Valencia: Universitat de València.

Hermon, E. (2014). Concepts environnementaux et la gestión integrée des bords de l'eau (riparia) dans l'Empire Romain: Une leçon du passé? En E. Hermon \& A. WATELET (Dirs.), Riparia, un patrimoine culturel: La gestión intégrée des bords de l'eau: Actes de l'atelier Savoirs et practiques de gestión intégrée des bords de l'eau: Riparia, Sudbury, 12-14 avril 2012 (pp. 9-18). Oxford: Archeopress. (BAR International Series, 2587).

KIRCHNER, H. (1995). Colonització de lo regne de Mallorques qui és dins la mar: La subversió feudal dels espais agraris andalusins a Mallorca. En P. SÉNAC (Ed.), Histoire et archéologie des terres catalanes au Moyen Age (pp. 279-316). Perpignan: Presses Universitaires de Perpignan.

KIRCHNER, H. (2003). Arqueologia colonial: Espais andalusins i pobladors catalans, 12291300. En M. Barceló, G. Feliu, A. Furió, M. Miquel \& J. Sobrequés (Eds.), El feudalisme comptat $i$ debatut: Formació $i$ expansió del feudalisme català (pp. 201-236). Valencia: Universitat de València.

KIRCHNER, H. (2012). Conquista y colonización feudal: Arqueología de los cambios producidos en los espacios irrigados de origen andalusí: El caso de las islas Baleares. En J. A. EIROA (Ed.), La conquista de al-Andalus en el siglo XIII (pp. 41-63). Murcia: Universidad de Murcia.

KIRCHNER, H. \& VirgiLI, A. (2018). Espacios agrarios en el Bajo Ebro en época andalusí y después de la conquista catalana (siglos XI-XIII). En J.TorRó \& E. GUINOT (Eds), Trigo y ovejas: El impacto de las conquistas en los paisajes andalusies (siglos XI-XVI) (pp. 15-49). Valencia: Universitat de València.

KirCHNER, H. \& Virgili, A. (2019). Espacios de cultivo vinculados a Madînat Țurțuša (Tortosa, Cataluña): Norias, drenajes y campesinos (siglos VIII-XII). Edad Media. Revista de Historia, (20), 83-112.

Kirchner, H., Virgili, A., Marfull, J., Pacheco, N., Pica, M. \& Rovira, M. (2016). Espais agraris, assentaments andalusins i la ciutat de Tortosa (Baix Ebre). En Actes I fornades d'Arqueologia de les Terres de l'Ebre (pp. 507-526). Tortosa: Generalitat de Catalunya. 
LALIENA, C. \& ORTEGA, J. (2012). Formas feudales de especulación agraria:Villas, viñas y acequias en el sur de Aragón (ca. 1170-1240). En J.TorRó \& E. GuINoT (Eds.), Hidráulica agraria y sociedad feudal: Prácticas, técnicas, espacios (pp. 79-102).Valencia: Universitat de València.

MALPICA, A. (2015). Le transformazioni agricole e l'avanzata cristiana nella Penisola Iberica. En I paesaggi agrari d'Europa (secoli XIII-XV):Ventiquattresimo Convegno Internazionale di Studi: Pistoia, 16-19 maggio 2013 (pp. 101-125). Pistoia/Roma: Centro italiano di studi di storia e d'arte /Viella.

MARTí, R. \& Negre, J. (2014). Fortificaciones y edilicia de prestigio en el extremo oriental de la Marca Superior: Turțûša y su entorno. En F. SABATÉ \& J. BRUfal (Eds.), La ciutat medieval i arqueología:VI Curs Internacional d'Arqueologia Medieval (pp. 219239). Lleida: Pagès.

MARTí, R. \& Negre, J. (2015). Assentaments i espais agraris medievals al Baix Ebre i Montsià: Una anàlisi diacrónica. Estudis d'Història Agrària, (27), 67-89.

MARTí, R. \& Negre, J. (2016). El poblament rural del Baix Ebre i el Montsià entre l'Antiguitat Tardana i el Feudalisme: Prospeccions arqueològiques a les Terres de l'Ebre entre els anys 2010 i 2011. En Actes. I fornades d'Arqueologia de les Terres de l'Ebre (pp. 491-506). Tortosa: Serveis Territorials de Cultura de les Terres de l'Ebre.

Martín, E. (2016). Paisajes imaginarios y paisajes reales a finales de la Edad Media: Humedales y marismas en las comarcas gaditanas. En M. I. DEL VAL VALDIVIESO (Coord.), El agua en el imaginario medieval: Los reinos ibéricos en la baja edad media (pp. 1740). Alicante: Universitat d'Alacant.

MARTíN, E. (2018). Los paisajes rurales en las comarcas gaditanas: Transformaciones y permanencias: Interacción entre sociedad y medio ambiente, siglos XIII al XV. En J. ToRRÓ \& E. GUINOT (Eds.), Trigo y ovejas: El impacto de las conquistas en los paisajes andalusies (siglos XI-XVI) (pp. 227-255). Valencia: Universitat de València.

Massip, J. (1996). Costums de Tortosa. Barcelona: Fundació Noguera.

Mateu, M. (2016). Estudi de les torres medievals del Baix Ebre: La torre de la Candela, la torre de Burjassénia, la torre de Camarles i la torre de l'Ermita de la Mare de Déu de l'Aldea. Trabajo de fin de grado. Barcelona: Universitat Autònoma de Barcelona. Monjo, M. (2012). La pervivencia del regadío andalusí en la Aitona bajomedieval. En J. TORRó \& E. GuINOT (Eds.), Hidráulica agraria y sociedad feudal: Prácticas, técnicas, espacios (pp. 207-224). Valencia: Universitat de València.

Negre, J. (2015). Orígenes y desarrollo de la huerta de Tortosa (siglos IV-XII): El proceso de formación de un macro-espacio irrigado en el levante peninsular. Historia Agraria, (66), 11-40.

ORTEGA, J. M. (2010). La agricultura de los vencedores y la agricultura de los vencidos: La investigación de las transformaciones feudales de los paisajes agrarios en el valle del Ebro (siglos XII-XIII). En H. KIRCHNER (Ed.), Por una arqueología agraria: Pers- 
pectivas de investigación sobre espacios de cultivo en las sociedades medievales hispánicas (pp. 123-146). Oxford: Archeopress. (BAR International Series, 2062).

Pagarolas, L. (1984). La Comanda del Temple de Tortosa, primer periode (1148-1213). Tortosa: Dertosa.

Pagarolas, L. (1998). La fi del domini de l'Orde del Temple a Tortosa: La permuta de 1294. Anuario de Estudios Medievales, (28), 269-291.

Pagarolas, L. (1999a). Els templers de les terres de l'Ebre (Tortosa): De faume I fins a l'abolició de l'Orde (1213-1312). Vol. 1. Tarragona: Diputació de Tarragona.

Pagarolas, L. (1999b). Els templers de les terres de l'Ebre (Tortosa): De faume I fins a l'abolició de l'Orde (1213-1312). Vol. 2. Tarragona: Diputació de Tarragona.

Phillips, J. (2007). The Second Crusade: Extending the Frontiers of Christendom. New Haven/London:Yale University Press.

Pluskowski, A., BoAs, A. J. \& GERRARD, C. (2011). The Ecology of Crusading: Investigating the Environmental Impact of Holy War and Colonisation at the Frontiers of Medieval Europe. Medieval Archaeology, (55), 192-225.

Puy, A., Balbo, A., Virgili, A. \& Kirchner, H. (2014). Wetland Reclamation in al-Andalus: The Drainage of Les Arenes Floodplain (Tortosa, Spain, $7^{\text {th }}-10^{\text {th }}$ centuries AD). Geoderma, (232-234), 219-235.

TORRÓ, J. (1995). L'assalt a la terra: Qüestions sobre l'abast de la colonització feudal al regne de València (1233-1304). En P. SÉNAC (Ed.), Histoire et archeologie des terres catalanes au Moyen Âge (pp. 317-338). Perpignan: Presses Universitaires de Perpignan.

TorRó, J. (1999). El naixement d'una colonia: Dominació $i$ resistència a la frontera valenciana (1238-1276).Valencia: Universitat de València.

ToRRó, J. (2003). Arqueologia de la conquista: Registre material, substitució de poblacions i transformació de l'espai rural valencià (segles XIII-XIV). En M. BARCELó, G. Feliu, A. Furió, M. Miquel \& J. Sobrequés (Eds.), El feudalisme comptat $i$ debatut: Formació $i$ expansió del feudalisme català (pp. 153-201).Valencia: Universitat de València.

TORRó, J. (2010). Tierras ganadas: Aterrazamiento de pendientes y desecación de marjales en la colonización cristiana del territorio valenciano. En H. KIRCHNER (Ed.), Por una arqueología agraria: Perspectivas de investigación sobre espacios de cultivo en las sociedades medievales hispánicas (pp. 157-173). Oxford: Archeopress. (BAR International Series, 2062).

ToRRó, J. (2012). Colonización cristiana y roturación de las áreas palustres en el reino de Valencia: Los marjales de la villa de Morvedre. En J. TorRó \& E. GuINot (Eds.), Hidráulica agraria y sociedad feudal: Prácticas, técnicas, espacios (pp. 147-185). Valencia: Universitat de València.

TORRÓ, J. (2019). Paisajes de frontera: Conquistas cristianas y transformaciones agrarias (siglos XII al XIv). Edad Media. Revista de Historia, (20), 13-46. 
ToRRó, J. \& Esquilache, F. (2018). Por donde jamás habían sido conducidas aguas: La transformación agraria del marjal norte de la Albufera de Valencia (siglos XIII-XV). En J. ToRRó \& E. GuINOT (Eds.), Trigo y ovejas: El impacto de las conquistas en los paisajes andalusíes (siglos XI-XVI) (pp. 161-225). Valencia: Universitat de València.

Torró, J. \& Guinot, E. (2018). Presentación. En J. TorRó \& E. Guinot (Eds.), Trigo y ovejas: El impacto de las conquistas en los paisajes andalusíes (siglos XI-XVI) (pp. 9-13). Valencia: Universitat de València.

TRILlo, C. (2012). El agua en el reino de Granada: Herencia islámica y transformaciones castellanas. En J. ToRRó \& E. GuINOT (Eds.), Hidráulica agraria y sociedad feudal: Prácticas, técnicas, espacios (pp. 261-285). Valencia: Universitat de València.

Virgili, A. (1997). Diplomatari de la catedral de Tortosa (1062-1193). Barcelona: Fundació Noguera.

VIRGILI, A. (2001a). Diplomatari de la catedral de Tortosa (1193-1212): Episcopat de Gombau de Santa Oliva. Barcelona: Fundació Noguera.

VIRGILI, A. (2001b). Ad detrimentum Yspanie: La conquesta de Turț̂িša i la formació de la societat feudal (1148-1200). Barcelona: Universitat de València/Universitat Autònoma de Barcelona.

VIRGILI, A. (2001c). Conqueridors i colons a la frontera: Tortosa, 1148-1212. Recerques. Història, Economia, Cultura, (43), 47-76.

VIRGILI, A. (2007). Les conquestes catalanes de segle XII i els repartiments. En E. GUINOT \& J. TORRÓ (Eds.), Repartiments medievals a la Corona d'Aragó (segles XII-XIII) (pp. 51-74).Valencia: Universitat de València.

VirgiLI, A. (2009). Angli cum multis aliis alienigenis: Crusade Settlers in Tortosa (Second Half of the Twelfth Century). Fournal of Medieval History, 35 (3), 297-312.

VIRGILI, A. (2010a). Espacios drenados andalusíes y la imposición de las pautas agrarias feudales en el prado de Tortosa (segunda mitad del siglo XII). En H. KIRCHNER (Ed.), Por una arqueología agraria: Perspectivas de investigación sobre espacios de cultivo en las sociedades medievales hispánicas (pp. 147-155). Oxford: Archeopress. (BAR International Series, 2062).

VIRGILI, A. (2010b). Gent Nova: Els processos de colonització de la Catalunya Nova (segles XII-XIII). Butlletí de la Societat Catalana d'Estudis Històrics, (21), 77-102.

VirgiLI, A. (2019). Sarraïns a la Catalunya Nova (segles XII-XIII). En F. SABATÉ (Ed.), Poblacions rebutjades, poblacions desplaçades (Europa Medieval) (pp. 45-70). Lleida: Pagès.

Virgili, A., EscolÀ, J. M., Pica, M. \& Rovira, M. (2018). Diplomatari de la catedral de Tortosa: Episcopats de Ponç de Torrella (1212-1254) i Bernat d'Olivella (1254-1272). Barcelona: Fundació Noguera. 